\title{
Description of a new species of Netomocera Bouček (Hymenoptera: Chalcidoidea: Pteromalidae) from Arunachal Pradesh, India, with a key to world species
}

\author{
P.M. Sureshan
}

Zoological Survey of India, Western Ghat Regional Centre, Kozhikode, Kerala 673006, India Email:pmsuresh43@yahoo.com

Abstract : A new species of Netomocera Bouček (Hymenoptera Pteromalidae) $N$. ramakrishnai $\mathrm{sp}$. nov. is described from Arunachal Pradesh, India. The affinities of the new species with other related species are discussed and a key to separate the world species (female) of Netomocera is also provided.

Keywords: Hymenoptera, India, Netomocera, new species, Pteromalidae.

Namdapha National Park is located in the Changlang District of Arunachal Pradesh located within $27^{\circ} 23^{\prime}-27^{\circ} 39^{\prime} \mathrm{N}$ \& 96 ${ }^{0} 15^{\prime}-96^{\circ} 58^{\prime} \mathrm{E}$. The area lies within the northeastern India which is one of the global hot spots of Biodiversity. Namdapha National Park supports a rich assemblage of flora and fauna and the vegetation of the area is

Date of publication (online): 26 November 2010

Date of publication (print): 26 November 2010

ISSN $0974-7907$ (online) | 0974-7893 (print)

Editor: Hui Xiao

\section{Manuscript details:}

Ms \# 02407

Received 20 February 2010

Final received 20 April 2010

Finally accepted 03 September 2010

Citation: P.M. Sureshan (2010). Description of a new species of Netomocera Bouček (Hymenoptera: Chalcidoidea: Pteromalidae) from Arunachal Pradesh, India, with a key to world species. Journal of Threatened Taxa 2(12): 1309-1312

Copyright: (C) P.M. Sureshan 2010. Creative Commons Attribution 3.0 Unported License. JoTT allows unrestricted use of this article in any medium for non-profit purposes, reproduction and distribution by providing adequate credit to the authors and the source of publication.

Acknowledgements: I am grateful to the Director, Zoological Survey of India, Kolkata and the Officer in charge, Zoological Survey of India, Western Ghat Regional Centre, Kozhikode for providing necessary facilities and encouragement. I am also grateful to Dr. John. S. Noyes, the Natural History Museum, UK and Dr. T.C. Narendran, Professor (Emeritus), University of Calicut, Kerala for providing important literature on Netomocera and encouragement. I am also thankful to Dr. J.K. De, Scientist D, Zoological Survey of India Kolkatta and Dr. G. Maheswaran, Scientist C and officer in charge, Zoological Survey of India, Arunacha Pradesh, Itanagar for giving me an opportunity to participate in the Namdapha expedition and providing all the necessary facilities. Thanks are also due the Wild life warden and other forest officials of Namdapha for permitting to visit the various localities in the area and providing necessary facilities.

\section{OPEN ACGESS I FREE DOWNLOAD (C) (i) (4)}

mainly tropical evergreen and semi evergreen forests. During the faunal exploration surveys conducted by the Zoological Survey of India, in the Namdapha National Park, an interesting species of Netomocera Bouček was collected from an evergreen forest patch. The specimens were collected by sweeping over the forest litter. Detailed studies of the specimens proved that they belong to an undescribed species which is described hereunder. The present species forms the second described species of Netomocera from the Oriental Region. Affinities of the new species with other known species were given and a key to separate the world species of Netomocera (females) is also provided here.

The genus Netomocera Bouček belongs to the subfamily Diparinae of the chalcidoid family Pteromalidae, species of which are nearly cosmopolitan in distribution except for the colder regions of the world. Among the members of subfamily Diparinae, Netomocera has rather robustbody and an asymmetrical antennal clava. The other characters of Netomocera are the sessile or subsessile gaster in both sexes, strong bristles on the vertex and the thoracic dorsum, truncate and slightly produced shiny clypeus and strong sickle-shaped mandibles. The biology of Netomocera species is totally unknown. Currently, the genus is known by seven described species throughout the world including the type species $N$. setifera Bouček described from Europe (Noyes 2003; Desjardins 2007). The other species are $N$. africana Hedqvist, $N$. alboscapus Hedqvist, $N$. rufa Hedqvist (all Afrotropical), N. nigra Sureshan \& Narendran (Oriental), N. sedlaceki Bouček (Australian) and $N$. nearctica Yoshimoto (Nearctic). Bouček (1988) mentioned the probable occurrence of about six species in the South Asia. Morphological terminology used in the paper follows that of Bouček (1988) and Gibson et al. (1997).

Abbreviations: F1-F7 - Funicular segments 1 to 7; MV - Marginal vein; OOL - Ocellocular distance; PMV - Postmarginal vein; POL - Postocellar distance; SMV - Submarginal vein; STV - Stigmal vein; T1-T4 - Gastral tergites 1 to 4; ZSIP - Zoological Survey of India, Gangetic Plains Regional Centre, Patna. 


\section{Netomocera ramakrishnai sp. nov. (Figs. 1-4, Images 1-3)}

Material examined: Holotype: Female, 7.xi.2009, 27032'18.8”N \& 96026'27.5”E, Baranalla, Namdapha National Park, Changlang District, Arunachal Pradesh, India, coll. J.K. De and party (ZSIP A.1345)

Paratype: 1 male same data as that of holotype (ZSIP A.1346); 11.xi.2009, 2 males, Firm base camp, Road towards Ranijheel, 27031'16.1"N \& 96029'52.9"E (ZSIP A.1347).

Etymology: The species is named in honour of Dr. Ramakrishna, Ex. Director, Zoological Survey of India, Kolkatta, India for his constant support and encouragement for my research.

Description: Female: Length $2.5 \mathrm{~mm}$. Head brownish-black, eyes silvery grey, ocelli silvery white; thorax reddish-brown with propodeum medially, anterior part of mesopleuron and ventral part of thorax black; gaster brownish-black except T2-T4 yellowish-brown (both dorsal and lateral aspects). Antennae with scape pale brownish-yellow, pedicel testaceous, remainder brown with club and preceding two segments blackishbrown. Legs uniformly brownish-yellow. Tegulae brown, wings hyaline, veins pale brown, bristles and pubescence brown.

Head: (Images 2 \& 3) Uniformly reticulate, meshes small, scrobe and parascorbal areas striate reticulate in the form of circular lines, lower face minutely reticulate; vertex declivous with three pairs of long brown bristles; in dorsal view head 2.5x as wide as long; POL almost $5 \mathrm{x}$ as long as OOL; temple very narrow almost reduced. Head 1.1x as broad as high in front view; anterior margin of clypeus slightly projecting forward and projecting from the general surface, almost completely shiny, margins clearly demarcated; malar grooves distinct; posterior margin of gena sharp but not carinate; eye length 1.6x width in profile. Antennae (Fig. 1, Images 2, 3) inserted

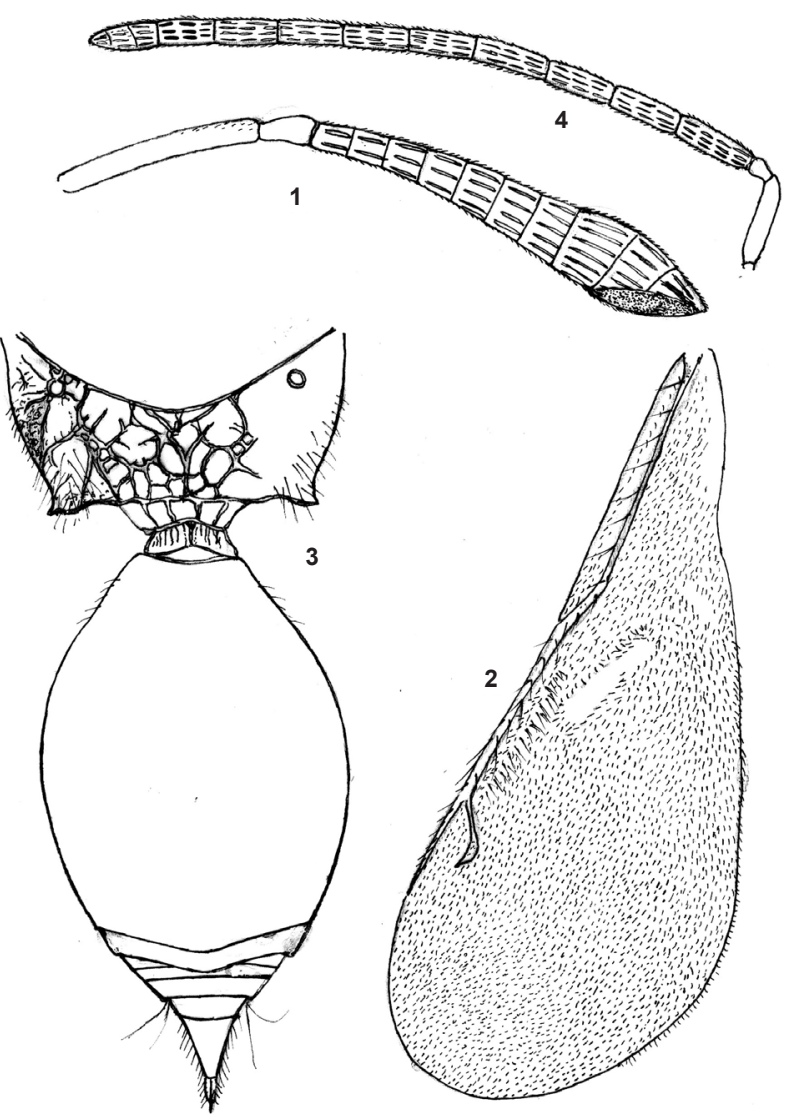

Figures 1-4. Netomocera ramakrishnai sp. nov. (Female) 1 - Antenna; 2 - Forewing; 3 - Propodeum and gaster dorsal view; 4 - Male antenna.

at level of lower ocular line; pedicel plus flagellum slightly shorter than head width; scape $0.9 x$ as long as eye, not reaching median ocellus and $6.5 x$ as long as broad, anelli very small and transverse; pedicel $2.5 x$ as long as wide and slightly longer than F1, F2 slightly shorter than F1, F2-F4 equal, F5-F7 almost equal, slightly shorter than
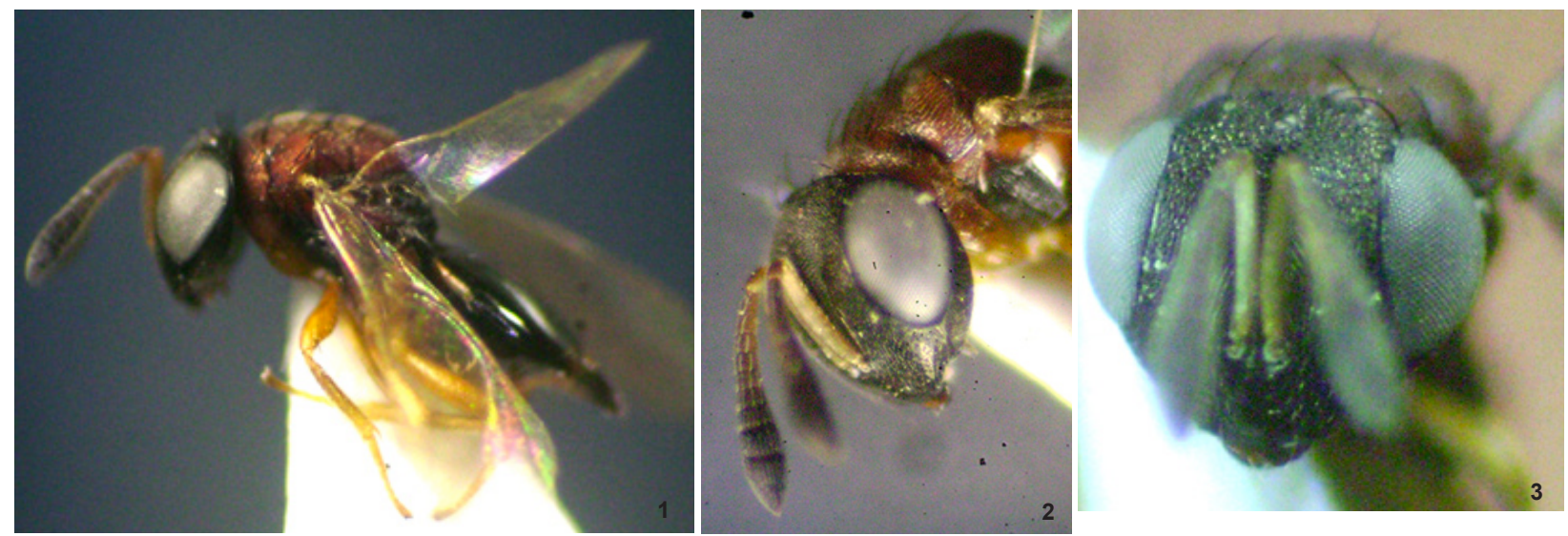

Images 1-3. Netomocera ramakrishnai sp. nov. (Female)

1 - Body in profile view; 2 - Head and part of thorax in profile view; 3 - Head in front view 
F4; funicular segments gradually broadening towards tip, flagellum moderately clavate, clava $1.9 x$ as long as broad and slightly longer than four preceding segments combined, sutures oblique, distinct, area of micropilosity reaching $2 / 3$ length, all funicular segments with a single row of long sensillae.

Thorax: (Images 1, 2) Prontoum 3.3x as broad as long, collar rounded and not carinate, anterior area with five long bristles, coriaceous reticulate, lateral panel transversely striate. Mesoscutum $3 x$ as broad as long, moderately reticulate with densely small hairs; notauli complete, middle lobe with four bristles and side lobes with one bristle each. Scutellum as long as broad with two pairs of strong bristles, frenum clearly marked, longitudinally striate reticulate; dorsellum fine with transverse rugae. Propodeum (Fig. 3) 2.75x as broad as median length, with uniformly irregular strong ridged reticulate, enclosing broad foveae, interior of which very finely reticulate and almost shiny, callus with dense white pubescence, plicae complete, median carina irregular, not complete, nucha small, posterior border emarginate, spiracles round, small, separated from hind margin of metanotum by own diameter. Prepectus long, triangular, longer than tegulae, coriaceous reticulate. Mesopleuron with mesepisternum striate reticulate, sub alar area polished, mesepimeron shiny, clearly demarcated from mesepisternum, posterior margin with a longitudinal broad groove and with transverse rugae inside; anterior part of metapleuron fine, posterior part reticulate. Hind coxa transversely ridged, posterior dorsal side with three long white hairs, anterior lateral border moderately and densely hairy, hind tibia with two short unequal spurs, fore and mid coxae very finely and transversely striate reticulate. Relative lengths: hind coxa 22, femur 31 , tibia 32 , tarsus 24 , basitarsus $2 x$ as long as second segment. Forewing (Fig. 2) 2.2x as long as broad, pubescence almost complete, dense, except for a narrow elongated speculum which is shiny, marginal fringe present only in the lower margin, veins with a row of strong brown bristles which is in double row on MV, a line of long white hairs below MV on ventral surface, basal cell completely hairy, costal cell $11 \mathrm{x}$ as long as broad, hairy in the upper half of ventral surface which is complete at tip. Relative lengths of SMV 35, MV 25, STV 7, PMV 13

Gaster: (Fig. 3) elongate ovate, $1.8 \mathrm{x}$ as long as broad in dorsal view (excluding petiole) and as long as head and thorax combined.(including petiole); petiole transverse, $2.3 x$ as broad as long, dorsally with strong longitudinal ridges inside of which is irregularly relticulate; $\mathrm{T} 1$ covering most of the gaster, $1.3 \mathrm{x}$ as long as broad, posterior margins of $\mathrm{T} 1$ and $\mathrm{T} 2$ slightly angulate, other tergites reduced, with hind margins straight, ovipositor slightly protruded; hypopygium reaching end of T4.

Male: Length $2.1 \mathrm{~mm}$. Differs from female in having short body which is completely black except for brown neck and lateral panel of pronotum. Legs except mid and hind coxae testaceous. Antennae (Fig. 4) with scape and pedicel testaceous remainder brownish-black, funicular segments elongated; antennal formula 11193; all funicular segments with numerous small sensillae and very small pubescence. Pubescence of lower face long; propodeum with median carina distinct; gaster short with petiole a little longer than broad with distinct longitudinal rugae; T1 covering most of the gaster, other tergites retracted; hind margin of T1 slightly emarginate; gaster including petiole $0.63 x$ as long as head and thorax combined.

Host: Unknown.

Key to the species of Netomocera Bouček (Females)

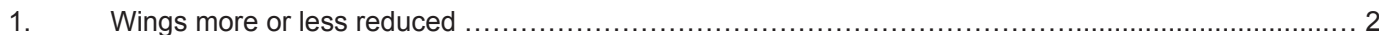

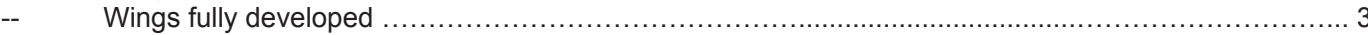

2. Gaster with T1 not reaching beyond half its length; scutellum with frenal line indistinct: Nearctic: Canada .N. nearctica Yoshimoto

-- $\quad$ Gaster with T1 reaching beyond half its length; scutellum with frenal line distinct. Australian: Australia:

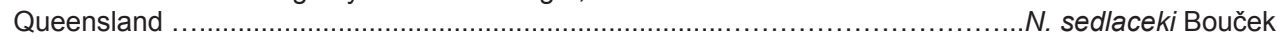

3. Fore wing with two fuscous spots, one below MV and the other at apex : Palearctic, Eastern Europe ...

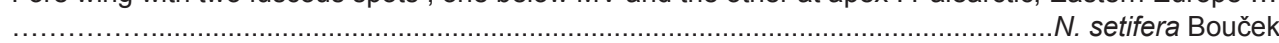
Forewing without fuscous spots, but sometimes with uniform brown Infumation ............................4

4. Antennae inserted distinctly above lower ocular line, eyes large, (2x as long as wide) malar space very short, less than $0.2 \times$ as long as eye (in profile): Afrotropical: Congo.................. alboscapus Hedqvist Antennae inserted just at lower ocular line; eyes not large, less than $2 x$ as long as broad; malar space not very short, more than $0.2 x$ as long as eye (in profile).

5. Gaster (excluding petiole) long, 2.65x as long as its maximum width; T1 not reaching middle of gaster. Afrotropical: South Africa ............................................................... africana Hedqvist Gaster (excluding petiole), oval or elongate oval, less than 2x as long as maximum Width; T1 reaching

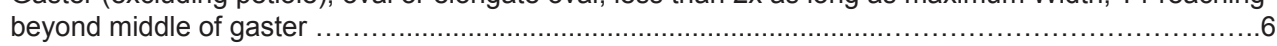

6. Gaster with hind margin of T1 distinctly emarginate, petiole as long as broad; forewing with uniform brown infumation. Oriental: India ............................................... nigra Sureshan \& Narendran Gaster (Fig. 3) with hind margin of T1 slightly angulate, petiole transverse, 2.3x as broad as long; forewing (Fig. 2) without brown infumation. Oriental: India..... ..N. ramakrishnai sp. nov. 
Remarks: In the nature of gaster, propodeum, shape of antenna (both male and female) N. ramakrishnai sp. nov. shows resemblance to $N$. sedlaceki Bouček, 1988 but in sedlaceki the wings are reduced. Except for the slight resemblance in the nature of antenna (both male and female antennae) the present species distinctly differs from the other Indian species $N$. nigra Sureshan \& Narendran, 1990 in having a different gaster, propodeum and body colour In the nature of antenna, head with large eyes and colouration $N$. ramakrishnai sp. nov. shows some resemblance to $N$. alboscapus Hedqvist, 1971 but in alboscapus the antennae are inserted distinctly above anterior margin of eyes, eyes longer than scpae and gaster with petiole as long as broad. In having an oval gaster with short petiole and in other general morphology the new species also resembles $N$. setifera Bouček, 1954 but in setifera the forewings have double infumation, antennae less clavate and gaster with hind margins of T1 not angulate. Males of $N$. ramakrishnai sp. nov. resemble $N$. rufa Hedqvist (described based on males) in the nature of antenna but differs in having malar space shorter than the breadth of an eye and body mostly black in colour. In $N$. rufa Hedqvist, malar space as long as the breadth of an eye and body predominantly brown. The males of $N$. rufa may prove to be the male of $N$. afriicana Hedqvist, 1971. Desjardins (2007: page 71) wrongly mentioned the holotype of $N$. rufa as female with other type details same as given by Hedqvist in the original description.

\section{REFERENCES}

Bouček, Z. (1988). Australasian Chalcidoidea (Hymenoptera). C.A.B. International Wallingford, U.K. 832pp.

Desjardins, C.A. (2007). Phylogenetics and classification of the world genera of Diparinae (Hymenoptera: Pteromalidae). Zootaxa 1647: 1-88.

Gibson, G.A.P., J.T. Huber \& J.B. Woolley (eds.) (1997). Annotated Keys to the Genera of Nearctic Chalcidoidea (Hymenoptera). NRC Research Press, Ottawa, Ontario, Canada, 794pp.

Hedqvist, K.J. (1971). Notes on Netomocera Bouč. with descriptions of new species (Hymenoptera: Chalcidoidea: Pteromalidae). Entomologisk Tidskrift 92: 237-241.

Noyes, J.S. (2003). Universal Chalcidoidea database. http://www. nhm.ac.uk/jdsml/research-curation/projects/chalcidoids. Last updated April 2009.

Sureshan, P.M. \& T.C. Narendran (1990). Taxonomic studies on Eurydinotomorpha and Netomocera (Hymenoptera: Chalcidoidea: Pteromalidae). Oriental Insects. 24: 219-227. 